\section{Stabilized municipal sewage sludge addition to improve properties of an acid mine soil for plant growth}

\section{M.D. Mingorance • S. Rossini Oliva • Benito Valdés • F.J. Pina Gata • Eduardo O.}

\section{Leidi • I. Guzmán • Aránzazu Peña}

M.D. Mingorance $\cdot$ A. Peña $(\bowtie)$

Instituto Andaluz de Ciencias de la Tierra (CSIC-UGR), Avda. Palmeras, 4, 18100-

Armilla, Granada, Spain

e-mail: aranchaph@iact.ugr-csic.es

\section{S. Rossini Oliva • B. Valdés • F.J. Pina Gata • I. Guzmán}

Department of Plant Biology and Ecology, University of Seville, Avda. Reina Mercedes s/n, 41012 Seville, Spain

\section{E.O. Leidi}

Department of Plant Biotechnology, IRNAS-CSIC, Avda. Reina Mercedes 10, 41012 Seville, Spain

Unidad Asociada CSIC-US "Estudio Integral del Medio Físico y Biótico" 3

\section{$(\bowtie)$ Corresponding author:}

Aránzazu Peña

Telephone number: 0034958230000

Fax number: 0034958552620

e-mail address: aranchaph@iact.ugr-csic.es 
Abstract

Purpose: Degraded soils, such as those encountered in areas of mine activities, need to be ameliorated by liming to correct soil acidity and by addition of organic inputs to improve soil properties and fertility.

Materials and methods: Non amended mine soil and soil amended with stabilized sewage sludge were incubated for $45 \mathrm{~d}$. Soil physicochemical and biological indicators were periodically measured along incubation and other enzyme activities at the end of incubation. In improved soils a study of plant development in $250-\mathrm{g}$ pots was carried out with three vegetal species: tomato, rye grass and ahipa. Germination and mortality rates, biomass production and photosynthetic pigments were measured.

Results and discussion: Soil incubation with sewage sludge slightly increased soil $\mathrm{pH}$ and led to an enhancement of soil electrical conductivity, organic carbon and dehydrogenase activity, especially for the higher doses (5 and 10\%). However soil respiration was more promoted with the $2 \%$ dose, pointing to a possible toxic effect of the sludge. At the end of incubation physicochemical and biological properties were in general enhanced. Biomass production was improved in tomato and rye grass by sewage sludge addition (more at the $2 \%$ dose) whilst ahipa growth was not affected by sewage sludge treatments. Tomato mortality reached $73 \%$ with high sludge doses (10\%).

Conclusions: According to this set of parameters, amendment with SSL of a limed acid mine soil would be considered as a good strategy for soil amelioration in view of plant establishment and development. 


\section{Introduction}

The Iberian Pyrite Belt occupies the southwestern corner of the Iberian Peninsula, extending from Seville, in Spain, to the Atlantic Ocean, south of Lisbon, in Portugal, making up a belt of about $230 \mathrm{~km}$ in length and $40 \mathrm{~km}$ in width (Sáez et al. 1996). It constitutes the world largest massive sulphide deposit (mainly $\mathrm{Cu}-\mathrm{Pb}-\mathrm{Zn}$ ), which has been mined since the Metal Age, according to archeometallurgical evidences, but reaching a peak between the 19 th and the 20th centuries, when most mines were closed due to exhaustion of the ore (Salkield 1987).

The soils in this belt are characterised by high level of acidity, poor physical structure and also contain toxic concentrations of metals and low levels of major plant nutrients (Fernández-Caliani et al. 2009). Even if some communities of pioneer plants colonized this area, it needs to be improved by different measures, which include correction of soil acidity and improvement of soil properties, because the extreme environmental conditions are not suitable to promote plant establishment. Besides, it is essential to assess the efficacy of the implemented measures by evaluating physical, chemical and biological properties, in order to gain a full understanding of constraints and opportunities.

Remediation of mine tailings by revegetation is an interesting approach with obvious economic and environmental advantages. However some of the limitations to revegetation on an acid soil include $\mathrm{pH}$ values out of physiological values, low nutrient status, low organic matter and microbial activity and low water holding capacity. Addition of organic amendments can increase organic matter, nutrient status, microbial activity and water holding capacity (Jones et al. 2012; González-Ubierna et al. 2012). The use of organic amendments together with liming or other materials rich in carbonates is a way of restoring the ecological function of metal-contaminated sites, given that these approaches improve the physicochemical and biological soil conditions and favour plant growth (Haynes and Swift 1988; Alvarenga et al. 2008, 2009; de Varennes et al. 2010) 
Organic amendments from different sources have been assayed for the improvement of mine soil conditions, from agricultural, industrial or miscellaneous origins (Alvarenga et al. 2008; de Varennes et al. 2010, 2011; Arocena et al. 2012). Furthermore, the use of organic wastes from water treatment plants is an alternative to the disposal of these residues, generated in huge quantities. The applications of these biowastes, whose production is estimated up to 138 million tonnes per year in the EU and with high potential added value, are regulated by a European Directive (Council Directive, ECC 1986) which considers both environmental and soil protection, encouraging the agricultural use of sewage sludge in such a way as to avoid harm to vegetation, animals or humans. In 2007 , 1.17 Mt of dry urban sewage sludges were produced in Spain, as a result of the treatment of almost $85 \%$ of the total residual water, in compliance with European guidelines (Council Directive, ECC 1991). The use of treated sewage sludges provides economic, agronomic and environmental benefits since they are low-cost amendments, have great fertilising ability and are a source of macro $(\mathrm{N}$ and $\mathrm{P})$ and micro (Fe, $\mathrm{Zn}, \mathrm{Cu}$, etc) nutrients. Additionally they increase soil organic matter content thus improving soil water-holding capacity, microbial activity, and other physical, chemical, and biological properties (Hueso et al. 2012).

The aims of this work were (a) to assess the effect of the addition of a stabilized sewage sludge of urban origin on physicochemical and biological properties of a severely degraded mine soil and (b) to study the effect of the amendment on the establishment of three plant species (tomato and rye grass, of agricultural interest and ahipa, a species which could be employed for biofuel production) and therefore their suitability to be used for revegetation.

\section{Materials and methods}

\subsection{Site description and properties of the soil and the amendment}


The soil (NC) was collected in a mine waste situated in the proximity of the village of

107 Nerva, province of Huelva (37॰42'4.5” N 6॰33'35.1” W), located in the Iberian Pyrite

108 Belt, which includes one of the largest deposits of pyrite $\left(\mathrm{FeS}_{2}\right)$ and other metallic and

109 polymetallic sulphides as chalcopyrite $\left(\mathrm{CuFeS}_{2}\right)$, sphalerite $((\mathrm{Zn}, \mathrm{Fe}) \mathrm{S})$ and galena $(\mathrm{PbS})$

110 (Chopin and Alloway 2007). Soil samples, characterised as sandy loam, were collected at

111 random from the selected site. They were air dried for 2 weeks, sieved through 3-mm for

112 incubation assays, or passed through a 2-mm mesh sieve or ground to $50 \mu \mathrm{m}$, for analysis

113 following standard methodology.

114 According to X-ray fluorescence analysis $\mathrm{SiO}_{2}(46.9 \%)$ and $\mathrm{Fe}(23.0 \%)$ and $\mathrm{Al}$

$115(12.7 \%)$ oxides represent more than $80 \%$ of the soil mineralogical composition. It is a very

116 acid soil $(\mathrm{pH} 2.4)$ with low organic carbon content (OC, 1.4\%), and high electrical

117 conductivity (EC, $1.3 \mathrm{dS} \mathrm{m}^{-1}, 1: 2.5$ ratio); 24\% water content at field capacity; HIX 1.16;

118 SUVA $\left(\mathrm{L} \mathrm{g}^{-1} \mathrm{~cm}^{-1}\right)$ 10.8. Otherwise, this soil contents high total concentrations of potential

119 hazardous elements $\left(\mathrm{mg} \mathrm{kg}^{-1}\right)(\mathrm{As}, 3951 ; \mathrm{Cu}, 694 ; \mathrm{Pb}, 3976)$ and also of S (8320).

120 Stabilized sewage sludge (SSL) from the wastewater treatment plant of Granada (SE

121 Spain), was used for the amendment of NC soil. The main properties are: $\mathrm{pH} 6.9$; EC (dS

$122 \mathrm{~m}^{-1}, 1: 10$ ratio) 2.8 ; OC (\%) 35.5; HIX 0.43.

123

124

\subsection{Soil incubation}

125 Mine soil (NC) was first limed with Carbocal (Azucarera Ebro), a residue rich in calcium

126 carbonate $(83.4 \%)$ with an $\mathrm{OC}$ content of $5.1 \%$. The limed Nerva soil $\left(\mathrm{NC}_{\mathrm{L}}\right)$ received

127 Carbocal at an equivalent rate of $1.5 \%(w / w)$ in $\mathrm{CaCO}_{3}$. After liming the organic waste

128 was applied at 2, 5 and 10\% (w/w) (SSL2, SSL5 and SSL10, respectively), corresponding

129 to approximately 40,100 and $200 \mathrm{Mg} \mathrm{ha}^{-1}$. The mixtures, carried out with air-dried soil and

130 the amendment, were placed in plastic trays covered with aluminium foil to avoid

131 desiccation, their moisture adjusted to $40 \%$ of the soil field capacity with deionised water, 
154 During incubation dehydrogenase activity (DHA), proposed as a measure of overall 155 microbial activity, was determined by incubating soil samples during $20 \mathrm{~h}$ at $25^{\circ} \mathrm{C}$ with 0.2

and allowed to stand in the dark at ambient temperature $\left(20 \pm 2{ }^{\circ} \mathrm{C}\right)$, up to $45 \mathrm{~d}$. Water was supplied as required to maintain soil humidity. One subsample was periodically withdrawn $(0,2,5,7,14,21,29,34,42$ and 49 days) for determination of $\mathrm{pH}$, moisture, conductivity and organic carbon (OC) content. Another subsample was kept frozen $\left(-18^{\circ} \mathrm{C}\right)$ until analysis for enzyme activities and soil induced respiration (SIR).

\subsection{Soil induced respiration and microbial biomass $\mathrm{C}$}

Soil induced respiration (SIR) measurements were performed in an automatic equipment ( $\mu$ Trac 4200, Sy-Lab, Gomensoro, Madrid, Spain), after defrozing the samples at ambient temperature. Briefly, ca. $5 \mathrm{~g}$ soil was mixed with $50 \mathrm{mg}$ of talc:glucose (10:1 ratio) and weighed into a plastic tube, which was introduced into a measuring cell containing $2 \mathrm{~mL}$ of a $2 \% \mathrm{KOH}$ solution. The tightly closed cell was maintained at $30^{\circ} \mathrm{C}$ during $20 \mathrm{~h}$ and $\mathrm{CO}_{2}$ evolution was monitored every $5 \mathrm{~min}$, through the measurement of solution impedance decrease. Results are expressed as $m g \mathrm{CO}_{2} 100 \mathrm{~g}^{-1} \mathrm{~h}^{-1}$.

Soil microbial biomass C (SMBC, mg C $100 \mathrm{~g}^{-1}$ soil) was estimated from the SIR assay. SMBC was calculated from the $\mathrm{CO}_{2}$ generated during $6 \mathrm{~h}$ of soil incubation as follows: $\mathrm{SMBC}=40.04 \times \mathrm{CO}_{2}+0.37$ (Anderson and Domsch 1978).

\subsection{Enzyme activities}

Enzyme activities are used as an index of microbial functional diversity if they reflect changes in microbial activities. Since microbial functional diversity includes many different metabolic processes, a representative set of enzyme activities was assessed: $\mathrm{mL}$ of $0.4 \%$ 2-p-iodophenyl-3 p-nitrophenyl-5 tetrazolium chloride as a substrate. The 
iodonitrotetrazolium formazan (INTF) formed was measured spectrophotometrically at 490

158

159

160

161

162

163

164 nm, according to García et al. (1997).

At the end of the incubation period various enzymes were analyzed: enzymes participating in the $\mathrm{C}$ cycle ( $\beta$-glucosidase), $\mathrm{N}$ cycle (protease), $\mathrm{P}$ cycle (alkaline phosphatase) and S cycle (arylsulphatase). The enzyme activities $\beta$-glucosidase (Glu), alkaline phosphatase (AlkP) and arylsulphatase (Aryl) were spectrophotometrically quantified at $400 \mathrm{~nm}$ by estimating the $p$-nitrophenol (PNP) released by incubating the soil with a substrate containing a p-nitrophenyl moiety (Tabatabai and Bremner 1970; Ladd and Butler 1972; Tabatabai 1994) and expressed as $\mu \mathrm{g}$ PNP g $\mathrm{g}^{-1} \mathrm{~h}^{-1}$. Protease activity (Pro) determined the released tyrosine reacted with Folin-phenol reagent measuring at $700 \mathrm{~nm}$ by spectrophotometry (Ladd and Butler 1972). This activity is expressed as $\mu \mathrm{g}$ tyrosine $\mathrm{g}^{-1}$ $\mathrm{h}^{-1}$. All enzyme activities were determined in defrozen samples in triplicate and expressed on an oven-dried $\left(105^{\circ} \mathrm{C}\right)$ soil basis.

\subsection{Analytical methods}

The soil particle size distribution was determined by sieving and sedimentation, applying the Robinson's pipette method after organic matter had been removed with $\mathrm{H}_{2} \mathrm{O}_{2}$, using sodium hexametaphosphate as dispersing agent. Field capacity was obtained from water retention of disturbed soil samples using ceramic pressure plates at an air pressure of 0.03 MPa. The $\mathrm{pH}$ and EC determinations were carried out in sample/deionised water suspensions 1/2.5 (w/v) for soil and mixtures of soil and sludge and 1/10 (w/v) for sludge. Organic C (OC) content was determined by a modified Walkey and Black method (Mingorance et al. 2007). The humification index (HIX) (Zsolnay 2003) and the specific UV absorbance (SUVA, L g ${ }^{-1} \mathrm{~cm}^{-1}$ ) (Hernández-Soriano et al. 2011) were determined in sample/deionised water suspensions $1 / 4(\mathrm{w} / \mathrm{v})$ at the end of the incubation period. Samples 
were analysed in triplicate. Estimation of metal content was accomplished by X-ray

183

184

185

186

187

188

189

190

191

192

193

194

196

197

198

199

200

201

202

203

204

205

206

fluorescence analysis.

\subsection{Pot experiments}

Three plant species were selected for the experiments: two of agricultural interest, tomato (Lycopersicon esculentum Mill.) and rye grass (Lolium perenne L.), and ahipa (Pachyrhizus ahipa (Wedd.) Parodi), whose tuberous root could be used for biofuel production. The experiment was carried out in pots of $250 \mathrm{~g}$ and under greenhouse conditions (average temperature $21.8^{\circ} \mathrm{C}$ and humidity $67 \%$ ). Non-amended limed soil $\left(\mathrm{NC}_{\mathrm{L}}\right)$ as a control and $\mathrm{NC}_{\mathrm{L}}$ amended with stabilized SSL at 2 and $10 \%$ (SSL2; SSL10) were the treatments tested.

In each pot the number of seeds was planted according to previous germination assays. The seeds showed the following germination rate: tomato $85 \%$, rye grass $95 \%$ and ahipa $70 \%$. A total of ten plants per pot were cultivated. Tap water was periodically added to maintain soil field capacity. In order to reduce soil compactness, $40 \mathrm{~g}$ of glass beads (4 $\mathrm{mm})$ were mixed in each pot.

Germination and mortality rates, biomass production and photosynthetic pigments were measured. Germination was monitored at the beginning and mortality at the end of the assays. The experiment was carried out during 18 days for rye grass and for one month for tomato and ahipa harvesting plants at vegetative stage. Fresh weight of the plant aerial vegetative part was only measured at the end of the experiment. Photosynthetic pigments were determined using a spectrophotometer (Thermo, Helios Gamma). A piece of leaf was taken and pigments were extracted with pure methanol for 24 hours and then the extract was measured. The concentrations of Chlorophyll a (Chl. a), b (Chl. b) and the sum of leaf carotenoids were calculated with the following equations given for pure methanol, where 
207 the pigment concentrations are given in $\mu \mathrm{g} \mathrm{mL}^{-1}$ extract solution (Lichtenthaler and 208 Buschmann 2001)

\subsection{Statistical treatment of the data}

215 Exploratory analysis was carried out to check normality of the data sets. Differences 216 between treatments were determined by ANOVA of normal data sets and Kruskal-Wallis 217 test of non-normal data sets. Otherwise, the post-hoc Tukey-t or Fisher's LSD (least 218 significant difference) tests were used for comparison of several means. Comparison 219 between two sample means was performed by $t$-test or Mann-Whitney test. The 220 relationship between variables was performed by either correlation or regression analysis.

221 Hierarchical cluster analysis was used to arrange the soil and plant properties into groups 222 using the Ward's method as linking algorithm and the square Euclidean distance as 223 similarity measurement. The clustering results were shown in a dendogram to provide 224 grouping of variables. used for statistical data analysis.

\section{Results and discussion}

\subsection{Evolution of soil physicochemical properties along incubation}

230 Addition of Carbocal as a liming agent effectively raised soil $\mathrm{pH}$ with an average value of $2316.8 \pm 0.18$ for the whole assayed period. The increase in $\mathrm{pH}$ as a result of liming has been 232 linked with a change in the charge characteristics of soil OC (Curtin and Smillie 1983; 
233 Chan and Heenan 1999). The $\mathrm{pH}$ increased 0.009 units per incubation day $\left(\mathrm{R}^{2}=0.812\right)$

234 reaching a value of 7.1 at the end of this period.

235 The addition of SSL modified soil $\mathrm{pH}$ depending on the applied dose. The $\mathrm{pH}$ for the 236 SSL2 treatment did not change with incubation time $(\mathrm{p}>0.05)$ and the overall $\mathrm{pH}$ average $237(6.9 \pm 0.15)$ was slightly higher than that of non-amended soil $(\mathrm{pH} 6.8 \pm 0.16)$, which 238 neither varied along the incubation $(\mathrm{p}>0.05)$. However, addition of 5\% SSL increased $\mathrm{pH}$ 239 linearly with incubation time $\left(\mathrm{R}^{2}=0.846 ; p H=6.71+0.02 \times t\right)$ and in the case of SSL10 $240 \mathrm{pH}$ also increased linearly during $17 \mathrm{~d}\left(\mathrm{R}^{2}=0.812 ; p H=6.39+0.07 \times t\right)$ and then 241 remained constant at a value of 7.7.

242 Soil EC also increased for limed soil, from 1.2 to $2.2 \mathrm{dS} \mathrm{m}^{-1}$, due especially to a strong 243 enhancement of $\mathrm{CO}_{3}{ }^{2-}$ and $\mathrm{Ca}^{2+}$ concentrations because of the Carbocal addition and of 244 formation of $\mathrm{SO}_{4}{ }^{2-}$ from the pyrite due to the $\mathrm{pH}$ increase (Curtin and Smillie 1983). 245 Amendment addition resulted in a further soil solution EC increase in comparison with 246 non-amended $\left(\mathrm{NC}_{\mathrm{L}}\right)$ soil. The $\mathrm{EC}$ of $\mathrm{NC}_{\mathrm{L}}(2.2 \pm 0.1)$ and of SSL2 (2.5 \pm 0.2$)$ remained 247 constant during incubation while that of SSL5 $\left(E C=2.3 \times t^{0.09}\right)$ and SSL10 $248\left(E C=2.4 \times t^{0.15}\right)$ increased with increasing incubation time following a power function 249 reaching final values of 3.2 and $4.1 \mathrm{dS} \mathrm{m} \mathrm{m}^{-1}$, respectively (Fig. 1). This increase was 250 probably as a consequence of the production of low molecular weight organic ions or of 251 the release of salts during decomposition of organic substances and agrees with soil EC 252 increases after addition of high doses of organic amendments to soil (González-Ubierna et 253 al. 2012). The increase in EC coincides with the increase in soil $\mathrm{pH}$ indicated above $254(\mathrm{r}=0.844)$. It is important to note that $4.0 \mathrm{dS} \mathrm{m}^{-1}$ has been reported as an EC value which 255 may inhibit plant growth and seed germination (Ye et al. 2002).

256 Soil OC was initially enhanced, as expected from the OC content of the organic waste, 257 and was proportional to the applied dose $\left(O C=1.5+0.34 \times\right.$ dose $\left.; \mathrm{R}^{2}=0.981\right)$ (see Fig. 1$)$. 258 Along incubation $\mathrm{OC}$ content of the non-amended $\mathrm{NC}_{\mathrm{L}}$ soil $(1.5 \pm 0.14)$ and amended with 
$2 \%$ SSL $(1.9 \pm 0.27)$ decreased slightly but without significant variations $(p>0.05)$. On the contrary, the OC of soils amended with 5 and $10 \%$ SSL decreased with time following a quadratic regression $\left(\mathrm{R}^{2}=0.850, \quad O C_{S S L 5}=3.4-0.08 \times t+0.002 \times t^{2} ; \quad \mathrm{R}^{2}=0.902\right.$, $O C_{S S L 10}=4.6-0.09 \times t+0.001 \times t^{2}$ ) likely as a result of OC mineralization in a stabilization process of the sludge (see Fig. 1).

\subsection{Evolution of soil biological properties with incubation}

To assess the results of soil remediation it is also necessary to observe the microbial processes, since soil biological investigations (such as soil respiration, biomass, enzyme activities, microbial counts) can give information on the presence of viable microorganisms. Biological methods can therefore be a good complement of physicochemical methods for the evaluation of amendment addition or for the assessment of the success of a remediation strategy.

Evolution of $\mathrm{CO}_{2}$ was low for untreated $\mathrm{NC}$ soil $\left(0.76 \mathrm{mg} \mathrm{CO}_{2} 100 \mathrm{~g}^{-1} \mathrm{~h}^{-1}\right)$, and increased with liming (3.49 $\mathrm{mg} \mathrm{CO}_{2} 100 \mathrm{~g}^{-1} \mathrm{~h}^{-1}$ ). The low $\mathrm{NC}$ respiration could be related with high soil metal pollution. Tyler (1974) showed a severe reduction of soil respiration with increasing concentrations of $\mathrm{Cu}$ and $\mathrm{Zn}$. On the contrary, lime application to acid soils is known to induce a temporary stimulation of soil biological activity and has been reported to enhance microbial biomass content, soil respiration rate, soil enzyme activities and net mineralization of soil organic N and S (Haynes and Swift 1988; Haynes and Naidu 1998). However it is also possible that dissolution of $\mathrm{CaCO}_{3}$ from the liming agent could

280 partially contribute to the emitted $\mathrm{CO}_{2}$ as has been recently indicated for soil carbonates 281 (Tamir et al. 2011).

282 The evolution of $\mathrm{CO}_{2}$ from soil amended with SSL was similar to that corresponding to 283 non-amended soil (Fig. 2). At the beginning of the incubation, the fact that soil respiration 284 increased more for the $2 \%$ amendment $(4.18 \pm 0.31)$ than for the higher doses $(3.21 \pm 0.43$ 
for SSL5 and $3.45 \pm 0.22$ for SSL10), which displayed a similar behaviour, could be an indication of SSL toxicity. Sewage sludges from the treatment of domestic waters may contain organic pollutants and potentially toxic elements (Smith 2009; Passuello et al. 2010), which could interfere or even inhibit the effective mineralization of labile organic compounds by soil microorganisms.

Dehydrogenase is an oxidoreductase only present in viable cells, therefore it has been considered to represent the average activity of the active microbial population of a soil (Nannipieri et al. 2002). Dehydrogenase activity (DHA) slightly increased with liming $\left(0.030 \mu \mathrm{g}\right.$ INTF $\mathrm{g}^{-1} \mathrm{~h}^{-1}$ for NC and $0.036 \mu \mathrm{g}$ INTF $\mathrm{g}^{-1} \mathrm{~h}^{-1}$ for $\left.\mathrm{NC}_{\mathrm{L}}\right)$, in agreement with previous reports (Badalucco et al. 1992), and was greatly promoted by addition of SSL (see Fig. 2), already after the first incubation day, proportionally to the SSL dose $\left(\mathrm{R}^{2}=0.991\right.$; $D H A=0.045+0.086 \times$ dose $\left.-0.0052 \times d o s e^{2}\right)$, suggesting that this fresh amendment provided $\mathrm{C}$ which could be metabolised by most soil microorganisms. Addition of $2 \% \mathrm{SSL}$ increased DHA values after 4 days of incubation, keeping the values constant along the incubation period, whereas SSL5 and SSL10 provided a strong increase with maximum DHA activity occurring between 4 and 12 days after amending (see Fig. 2). Then a concomitant reduction in DHA values was observed, which should be related to the decrease of easily-degradable substrates (Serra-Wittling et al. 1996; Saviozzi et al. 2002), in coincidence with a decline of the OC concentration in the soil (see Fig. 1).

\subsection{Soil properties at the end of the incubation period}

Table 1 shows the enhancing effects of SSL on soil properties after 45 days of incubation. Soil $\mathrm{pH}$ increased with SSL addition, and the increases in EC and OC content were proportional to the added dose $\left(\mathrm{R}^{2} 0.999, \quad E C=2.25+0.19 \times\right.$ dose $; \mathrm{R}^{2} 0.812$, $O C=0.17+0.17 \times$ dose $).$ The characterization of the more available OC fraction for soil microorganisms and plants, dissolved OC (DOC), showed that SSL addition diminished its 
311 aromaticity and humification degree. Both HIX and SUVA indexes displayed low values

312 for amended soils, decreasing proportionally to the dose $\left(\mathrm{R}^{2}=0.962\right.$,

$313 S U V A=1.83-0.27 \times$ dose $+0.02 \times$ dose $\left.^{2}\right)$.

314 The enzyme activities of non-amended soil without liming (data not shown) were

315 below those corresponding to agricultural soils (Trasar-Cepeda et al. 2000) probably 316 reflecting the toxic effect of some metals in this soil (Kandeler et al. 1996). It has been 317 shown that increasing metal concentrations $(\mathrm{Ni}, \mathrm{Cd}$ or $\mathrm{Pb})$, reduce some biochemical 318 indicators such as enzyme activities (Tejada et al. 2008; Khan et al. 2010). It is long known 319 that incorporation of organic matter modifies soil biochemical activity and can change the 320 effects of heavy metal to selected soil biochemical parameters. However, the influence of $321 \mathrm{OM}$ on soil biological properties depends upon amount, type, size and dominant 322 component of added organic materials (Tejada et al. 2008).

As can be seen in Table 1, changes in biological properties by SSL incorporation were 324 also noteworthy. However, the consideration of soil properties individually has proven 325 generally to be unsatisfactory in providing an appropriate estimate of soil quality. It is 326 difficult to draw meaningful conclusions about soil quality using individual soil enzyme 327 activities, because a particular soil enzyme activity is not strongly related to a specific soil 328 property but rather to a range of soil properties. Therefore, an overall index, i.e. the geometric mean of the assayed enzyme activities

$330\left(\right.$ GMea $\left.=(D H A \times G l u \times A l k P \times \operatorname{Pr} o \times A r y l)^{1 / 5}\right)$ was used to assess soil functioning (García331 Ruíz et al. 2008; Paz-Ferreiro et al. 2012). GMea was significantly higher in the 332 organically-amended soil than in non-amended soil (see Table 1). This value was highly 333 dependent on the dose $\left(\mathrm{R}^{2}=0.965\right.$, GMea $=3.43 \times$ dose $)$, confirming the improvement of 334 soil quality due to the addition of increasing SSL doses. In fact the enhanced enzyme 335 activities fell into the range of the values found in earlier studies (63-202 $\mu \mathrm{g} \mathrm{PNP} \mathrm{g}{ }^{-1} \mathrm{~h}^{-1}$ for 
glucosidase and 4.2-59.8 $\mu \mathrm{g}$ PNP $\mathrm{g}^{-1} \mathrm{~h}^{-1}$ for arylsulfatase) (Trasar-Cepeda et al. 2000) relative to agricultural soils.

A better understanding of the role of these enzymes on soil functioning is obtained by re-examining them individually, as they are related to the mineralization of relevant nutrients. Glu, an extracellular enzyme related to the C-cycle, catalysing the hydrolysis of cellobiose and other disaccharides, releasing sugars that act as energy source for microorganisms and Pro, which is related to the N-cycle and involved in the release of inorganic $\mathrm{N}$ from simple peptidic substrate, strongly increased with SSL addition (see Table 1), in agreement with Alvarenga et al. (2009) who reported increases in both enzymatic activities after addition of SSL between 25 and $100 \mathrm{Mg} \mathrm{ha}^{-1}$ to an acid mine soil. It is clear that the $\mathrm{N}$ cycle was modified when the mine soil was treated with SSL, since Pro was stimulated even at the lowest SSL dose (Table 1). Glu reflects the state of the organic matter and the processes occurring therein (García et al., 1994). The activity was low for control soil and increased with amendment addition, likely as a consequence of the higher content of labile $\mathrm{C}$ in the soil, as corroborated by SUVA and HIX values for soil DOC (Table 1).

AlkP, used to describe a wide group of enzymes which catalyze the hydrolysis of organic-P compounds to phosphates, and DHA also showed an increase with SSL at the end of the incubation period (see Table 1). The supply of readily metabolizable C in SSL may have been responsible for the stimulation in the synthesis of soil AlkP activity. The variations of the Aryl behaviour, an enzyme which hydrolyzes sulfate esters with an aromatic radical, were lower without showing a relationship with SSL addition, as previously reported (Paz-Ferreiro et al. 2012).

SIR did not follow any clear trend at the end of incubation, indicating that a SSL dose above 2\% would decrease microbial activity. De Andrés et al. (2012) also reported that sewage sludge application generally increased soil respiration, although in a manner not 
proportional to the quantity applied. On the other hand, Paz-Ferreiro et al. (2012) attributed

363 the decrease in soil respiration by sewage sludge addition to the solubility of heavy metals

364 in soil, while enzymatic activities were enhanced.

365 In general, the organic amendment stimulated soil enzymatic activities because the 366 added material may contain intra- and extracellular enzymes, as well as labile organic 367 matter fractions which may also improve microbial activity in the amended soil. The large 368 OC content of SSL would provide an energy source for soil microorganisms, but in 369 particular, the metal load of this mine soil, with toxic effects on soil microbiota, could be 370 counterbalanced in SSL-amended soil by the chemical composition of its OM, which 371 would be effective in binding and chelating the metals from the soil. Similar results were 372 reported by Tejada et al. (2008) in an acid-amended soil. However, due to the intrinsic 373 chemical complexity of DOC, it is difficult to predict DOC reactivity (Weisshaar et al. 374 2003)

\subsection{Screening of plant growth}

377 The growth of ahipa was not inhibited by SSL treatments and none of the parameters studied were affected $(\mathrm{p}>0.05)$. This means that this species does not need any soil correction to grow, except Carbocal addition to raise the soil $\mathrm{pH}$.

In rye grass, SSL amendment increased significantly $(\mathrm{p}<0.05)$ the biomass production

381 in comparison with non-amended soil, presenting significantly greater growth at $2 \%$, but 382 without significant differences between treatments $(\mathrm{p}>0.05)$ in photosynthetic pigments, 383 germination or mortality rate (Table 2).

384 Soil added with SSL2 (Fig. 3) led to an increase of biomass production of tomato ( $\mathrm{p}=$ 385 0.013), but SSL10 produced a growth inhibition, resulting in biomass values similar to 386 non-amended soil $(\mathrm{p}=0.695)$. Actually, at 0 and $2 \%$ SSL no mortality was recorded but it 387 reached values ranging from 58 to $100 \%$ with addition of SSL10. At the highest SSL 
application, tomato stunted growth and later plant death might have resulted by the significant increase in soil EC (Table 1) (the species is more sensitive to salinity at 390 germination and early seedling stage, see Foolad 1996). Inhibition of plant growth in soils 391 of high salinity has been reported for other vegetal species when added with sewage sludge 392 or other organic amendments (Gascó and Lobo 2007; Pardo et al. 2011). However, other 393 effects should not be discarded like overcoming toxicity thresholds either from metals in 394 the sludge or in the contaminated soil. In tomato, the SSL treatment had a positive effect 395 on photosynthetic pigments (see Table 2), being significantly higher in plants growing in 396 amended soil as compared to non amended soil $(\mathrm{p}<0.05)$ without showing significant 397 differences between doses $(\mathrm{p}>0.05)$. Estimation of chlorophyll content is often 398 accomplished to assess the impact of most environmental stresses as the pigment content is linked to toxicity/deficiency symptoms and photosynthetic plant productivity (Gupta and Sihna 2007). Our results are in agreement with earlier reports (Gupta and Sihna 2007; 401 Singh and Sihna 2005) and may be attributed to the improved bioavailability in the soil of 402 elements required for chlorophyll biosynthesis or the additional supply of nutrients from 403 the sludge. Carotenoids, protective pigments associated to chlorophylls, increase 404 sometimes under stress conditions (Kenneth et al. 2000; Rossini et al. 2010) and the results 405 suggest the metal contamination of the soil and the metal contribution of sludge 406 application.

407 An exploratory cluster data analysis (see Fig. 3), carried out to discover similarities 408 among the main soil properties and the plant growing indicators, revealed that plant 409 mortality was related with soil properties and the dose of SSL; the biomass and pigment 410 content were related with soil respiration, an indicator of soil fertility; finally, the third 411 group is related with the quality of DOC but seems not to be related with plant growth. 412 There is clear evidence that addition of SSL had a strong effect on plant establishment and 413 at the same time a dose increase resulted in an improvement of the soil biological activity 
and microbial efficiency and, depending on the species, of the plant growth.

Finally, if we focus on individual plant species, ahipa and rye grass grow well up to SSL10, while a dose $>2 \%$ negatively affects tomato establishment.

\section{Conclusions}

The addition of organic amendments to degraded soils, such as those from acid mining areas, should be selected taking into consideration not only soil fertility, but also soil ability to protect the underlying saturated zone from pollution and the ability to constitute an optimum ecosystem for the introduction of appropriate plants for revegetation purposes. Addition of SSL from urban treatment plants resulted in an initially enhanced soil OC, though it decreased with time as a result of sludge stabilization, and a general increase of biological and biochemical parameters (enzymatic activities and soil respiration). According to this set of parameters, soil amended with SSL would be considered as a good candidate for soil revegetation and plant establishment and development. All the species tested (tomato, rye grass and ahipa), with different economic and agricultural interest, could be used for revegetation after liming this soil for $\mathrm{pH}$ correction and the use of the amendment at $2 \%$, which implies less economic investment, might be recommended for the establishment of tomato plants. However to confirm the observed effects attained with

432 the present approach, based on a screening carried out with the three plant species in small pots, a future test under field conditions will be required.

Acknowledgements Thanks to Proyecto de Excelencia, Junta de Andalucía (P10RNM5814), cofinanced with European FEDER-FSE funds. The technical assistance of

437 Isabel Cañadas is gratefully acknowledged. EMASAGRA is thanked for the kind supply of 438 stabilized sewage sludges. Carbocal was kindly provided by Juan Castellano Márquez. 


\section{References}

441 Alvarenga P, Palma P, Gonçalves AP, Baião N, Fernandes RM, de Varennes A, Vallini G,

442 Duarte E, Cunha-Queda AC (2008) Assessment of chemical, biochemical and 443 ecotoxicological aspects in a mine soil amended with sludge of either urban or industrial $444 \quad$ origin. Chemosphere $72: 1774-1781$

445 Alvarenga P, Palma P, Gonçalves AP, Baião N, Fernandes RM, de Varennes A, Vallini G, 446 Duarte E, Cunha-Queda AC (2009) Organic residues as immobilizing agents in aided 447 phytostabilization: (II) Effects on soil biochemical and ecotoxicological characteristics. 448 Chemosphere 74:1301-1308

449 Anderson JPE, Domsch KH (1978) Physiological method for quantitative measurement of 450 microbial biomass in soils. Soil Biol Biochem 10:215-221

451 Arocena JM, van Mourik JM, Faz Cano A (2012) Granular soil structure indicates 452 reclamation of degraded to productive soils: A case study in southeast Spain. Can J Soil $453 \quad$ Sci $92: 243-251$

454 Badalucco L, Grego S, Dell'Orco S, Nannipieri P (1992) Effect of liming on some 455 chemical, biochemical, and microbiological properties of acid soils under spruce (Picea 456 abies L.). Biol Fertil Soils 14:76-83.

457 Chan KY, Heenan DP (1999) Lime-induced loss of soil organic carbon and effect on 458 aggregate stability. Soil Sci Soc Am J 63:1841-1844

459 Chopin EIB, Alloway BJ (2007) Trace element partitioning and soil particle 460 characterisation around mining and smelting areas at Tharsis, Ríotinto and Huelva, SW $461 \quad$ Spain. Sci Total Environ 373:488-500

462 Council Directive 86/278/EEC Directive on the protection of the environment, and in 463 particular of the soil, when sewage sludge is used in agriculture. 12 June 1986

464 Council Directive 91/2717EEC. Directive concerning urban waste-water treatment. 21 $465 \quad$ May 1991 
466 Curtin D, Smillie GW (1983) Soil solution composition as affected by liming and 467 incubation. Soil Sci Soc Am J 47:701-707

468 de Andrés EF, Tenorio JL, Albarran MD, Walter I (2012) Carbon dioxide flux in a soil 469 treated with biosolids under semiarid conditions. Compost Sci Util 20:43-48

470 de Varennes A, Abreu MM, Qu G, Cunha-Queda C (2010) Enzymatic activity of a mine 471 soil varies according to vegetation cover and level of compost applied. Int J $472 \quad$ Phytoremediat 12:371-383

473 de Varennes A, Qu G, Cordovil C, Gonçalves P (2011) Soil quality indicators response to 474 application of hydrophilic polymers to a soil from a sulfide mine. J Hazard Mater $475 \quad 192: 1836-1841$

476 Fernández-Caliani JC, Barba-Brioso C, González I, Galán E (2009) Heavy metal pollution 477 in soils around the abandoned mine sites of the Iberian Pyrite Belt (Southwest Spain). $478 \quad$ Water Air Soil Pollut 200:211-226

479 Foolad MR (1996) Response to selection for salt tolerance during germination in tomato $480 \quad$ seed derived from P.I. 174263. J Am Soc Hort Sci 121:1006-1011

481 Gascó G, Lobo MC (2007) Composition of a Spanish sewage sludge and effects on treated 482 soil and olive trees. Waste Manage 27:1494-1500

483 García C, Hernández T, Costa F, Ceccanti B (1994) Biochemical parameters in soils 484 regenerated by the addition of organic wastes. Waste Manage Res 12:457-466.

485 García C, Hernández T, Costa F (1997) Potential use of dehydrogenase activity as an index 486 of microbial activity in degraded soils. Commun Soil Sci Plant 28:123-134.

487 García-Ruiz R, Ochoa V, Hinojosa MB, Carreira JA (2008) Suitability of enzyme activities 488 for the monitoring of soil quality improvement in organic agricultural systems. Soil Biol 489 Biochem 40:2137-2145

490 González-Ubierna, S, Jorge-Mardomingo I, Carrero-González B, de la Cruz MT, 491 Casermeiro MA (2012) Soil organic matter evolution after the application of high doses 

1268

494 Gupta AK, Sinha S (2007) Phytoextraction capacity of the Chenopodium album L. grown 495 on soil amended with tannery sludge. Bioresource Technol 98:442-446

496 Haynes RJ, Naidu R (1998) Influence of lime, fertilizer and manure applications on soil 497 organic matter content and soil physical conditions: a review. Nutr Cycl Agroecosys $51: 123-137$

Haynes RJ, Swift RS (1988) Effects of lime and phosphate additions on changes in enzyme 500 activities, microbial biomass and levels of extractable nitrogen, sulphur and phosphorus 501 in an acid soil. Biol Fertil Soils 6:153-158

502 Hernández-Soriano MC, Degryse F, Smolders E (2011) Mechanisms of enhanced 503 mobilisation of trace metals by anionic surfactants in soil. Environ Pollut 159:809-815

504 Hueso S, Brunetti G, Senesi N, Farrag K, Hernández T, García C (2012) Semiarid soils 505 submitted to severe drought stress: Influence on humic acid characteristics in organic$506 \quad$ amended soils. J Soils Sediments 12:503-512

507 Jones BEH, Haynes RJ, Phillips IR (2012) Addition of an organic amendment and/or 508 residue mud to bauxite residue sand in order to improve its properties as a growth 509 medium. J Environ Manage 95:29-38

510 Kandeler E, Luxhoi J, Tscherko D, Magid J (1996) Influence of heavy metals on the 511 functional diversity of soil microbial communities. Biol Fertil Soils 23:299-306

512 Kenneth E, Pallet KE, Young J (2000) Carotenoids. In: Ruth GA, Hess JL (eds) 513 Antioxidants in Higher Plants. CRC Press, Boca Raton, FL, pp 60-81.

514 Khan S, Hesham AEL, Qiao M, Rehman S, He JZ (2010) Effects of Cd and Pb on soil 515 microbial community structure and activities. Environ Sci Pollut Res 17:288-296

516 Ladd JN, Butler JHA (1972) Short-term assays of soil proteolytic enzyme activities using 517 proteins and dipeptide derivatives as substrates. Soil Biol Biochem 4:19-30. 
Lichtenthaler HK, Buschmann C (2001) Chlorophylls and carotenoids: Measurement and characterization by UV-VIS spectroscopy. Curr Protoc Food Analyt Chem F4.3.1-F4.3.8

520 Mingorance MD, Barahona E, Fernández-Gálvez J (2007) Guidelines for improving 521 organic carbon recovery by the wet oxidation method. Chemosphere 68:409-413.

522 Nannipieri P, Kandeler E, Ruggiero P (2002) Enzyme activities and microbiological and 523 biochemical processes in soil. In: Burns RG, Dick RP (eds) Enzymes in the 524 environment. Activity, ecology and applications. Marcel Dekker, N.Y. Chapter 1, pp 152533.

526 Pardo T, Clemente R, Bernal MP (2011) Effects of compost, pig slurry and lime on trace 527 element solubility and toxicity in two soils differently affected by mining activities. $528 \quad$ Chemosphere 84:642-650

529 Passuello A, Mari M, Nadal M, Schuhmacher M, Domingo JL (2010) POP accumulation 530 in the food chain: integrated risk model for sewage sludge application in agricultural $531 \quad$ soils. Environ Int 36:577-583

532 Paz-Ferreiro J, Gascó G, Gutiérrez B, Méndez A (2012) Soil biochemical activities and the 533 geometric mean of enzyme activities after application of sewage sludge and sewage $534 \quad$ sludge biochar to soil. Biol Fertil Soils 48:511-517

535 Rossini Oliva S, Mingorance MD, Valdés B, Leidi EO (2010) Uptake, localisation and 536 physiological changes in response to copper excess in Erica andevalensis. Plant Soil $537 \quad 328: 411-420$

538 Sáez R, Almodóvar GR, Pascual E (1996) Geological constraints on massive sulphide 539 genesis in the Iberian Pyrite Belt. Ore Geol Rev 11:429-451

540 Salkield LU (1987) A technical history of the Rio Tinto mines. Some notes on exploitation 541 from pre-phoenician times to 1950s. The Institution of Mining and Metallurgy, $114 \mathrm{pp}$ 
Saviozzi A, Bufalino P, Levi-Minzi R, Riffaldi R (2002) Biochemical activities in a

543 degraded soil restored by two amendments: a laboratory study. Biol Fertil Soils 35:96$544 \quad 101$

545 Serra-Wittling C, Houot S, Barriuso E (1996) Modification of soil water retention and 546 biological properties by municipal solid waste compost. Compost Sci Util 4: 44-52

547 Singh S, Sinha S (2005) Accumulation of metals and its effects in Brassica juncea L.

548 Czern. (var. rohini) grown on various amendments of tannery waste. Ecotox Environ Saf $549 \quad 62: 118-127$

550 Smith SR (2009) A critical review of the bioavailability and impacts of heavy metals in 551 municipal solid waste composts compared to sewage sludge. Environ Int 35:142-156

552 Tabatabai MA, Bremner JM (1970) Arylsulfatase activity of soils. Soil Sci Soc Am Proc $553 \quad 34: 225-229$

554 Tabatabai MA (1994) Soil enzymes. In: Mickelson SH, Bigham, JM (eds) Methods of soil 555 analysis. Part 2. Soil Science Society of America. pp 775-833

556 Tamir G, Shenker M, Heller H, Bloom PR, Fine P, Bar-Tal A (2011) Can soil carbonate 557 dissolution lead to overestimation of soil respiration? Soil Sci Soc Am J 75:1414-1422

558 Tejada M, Moreno JL, Hernandez MT, García C (2008) Soil amendments with organic 559 wastes reduce the toxicity of nickel to soil enzyme activities. Eur J Soil Biol 44:129-140.

560 Trasar-Cepeda C, Leirós MC, Seoane S, Gil-Sotres F (2000) Limitations of soil enzymes 561 as indicators of soil pollution. Soil Biol Biochem 32:1867-1875

562 Tyler G (1974) Heavy metal pollution and soil enzymatic activity. Plant Soil 41:303-311

563 Weishaar JL, Aiken GR, Bergamaschi BA, Fram MS, Fujii R, Mopper K (2003) 564 Evaluation of specific ultraviolet absorbance as an indicator of the chemical composition 565 and reactivity of dissolved organic carbon. Environ Sci Technol 37:4702-4708 
566 Ye ZH, Shu WS, Zhang ZQ, Lan CY, Wong MH (2002) Evaluation of major constraints to 567 revegetation of lead/zinc mine tailings using bioassay techniques. Chemosphere $568 \quad 47: 1103-1111$

569 Zsolnay A (2003) Dissolved organic matter: artefacts, definitions and functions. Geoderma $570 \quad 113: 187-209$

571

572 


\section{Figure caption sheet}

574

575 Fig. 1 Evolution during incubation of electrical conductivity (left) and soil organic carbon

576 (right) for limed Nerva soil $\left(\mathrm{NC}_{\mathrm{L}}\right)$ amended with stabilized sewage sludge (SSL) at 0, 2, 5

577 and $10 \%$

578

579 Fig. 2 Evolution during incubation of soil induced respiration (left) and dehydrogenase

580 activity (right) for limed Nerva soil $\left(\mathrm{NC}_{\mathrm{L}}\right)$ amended with stabilized sewage sludge (SSL) at

$581 \quad 0,2,5$ and $10 \%$

582

583 Fig. 3 Dendrogram for hierarchical clustering of soil and plant variables 


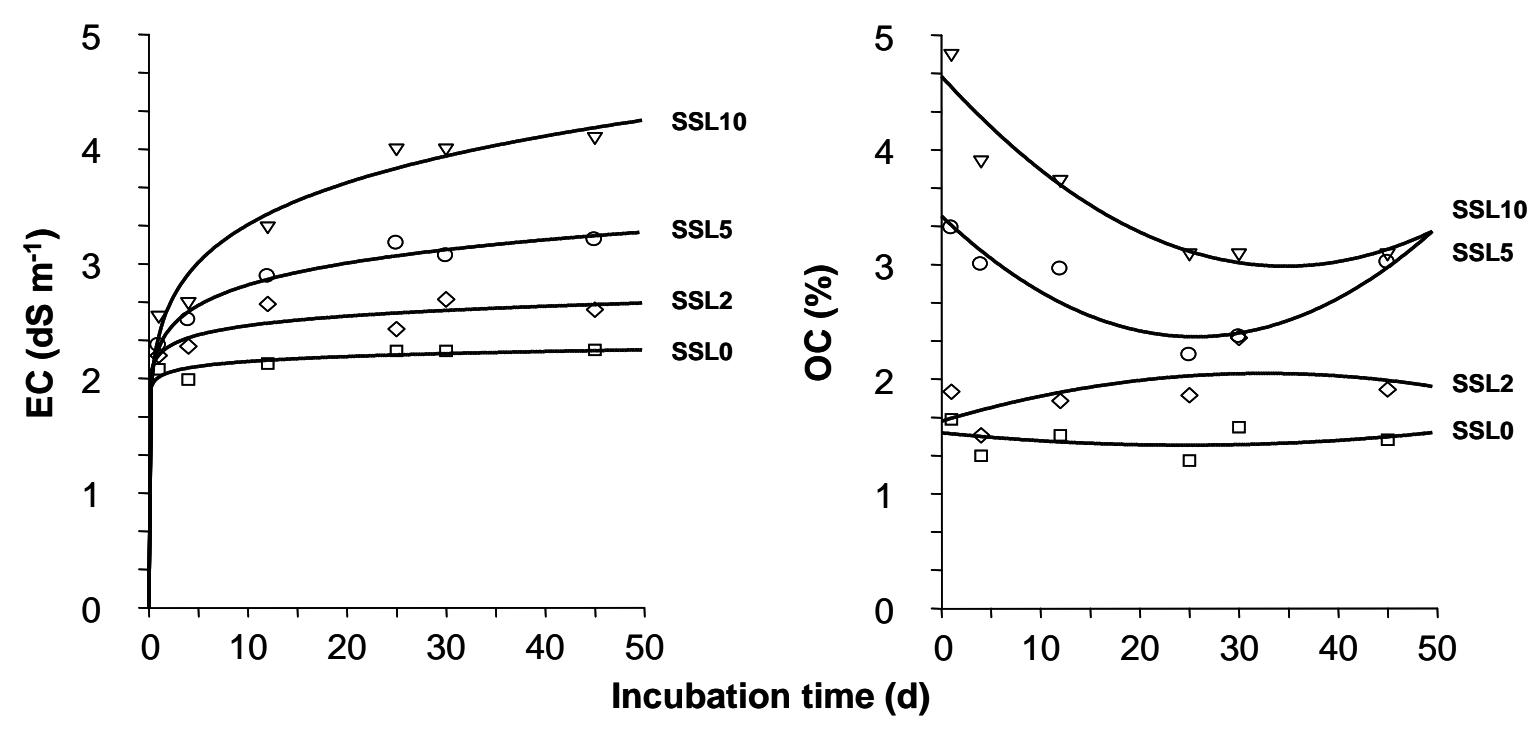

Figure 1. Evolution during incubation of electric conductivity (left) and soil organic carbon (right) for limed Nerva soil $\left(\mathrm{NC}_{\mathrm{L}}\right)$ amended with stabilized sewage sludge (SSL) at $0,2,5$ and $10 \%$. 

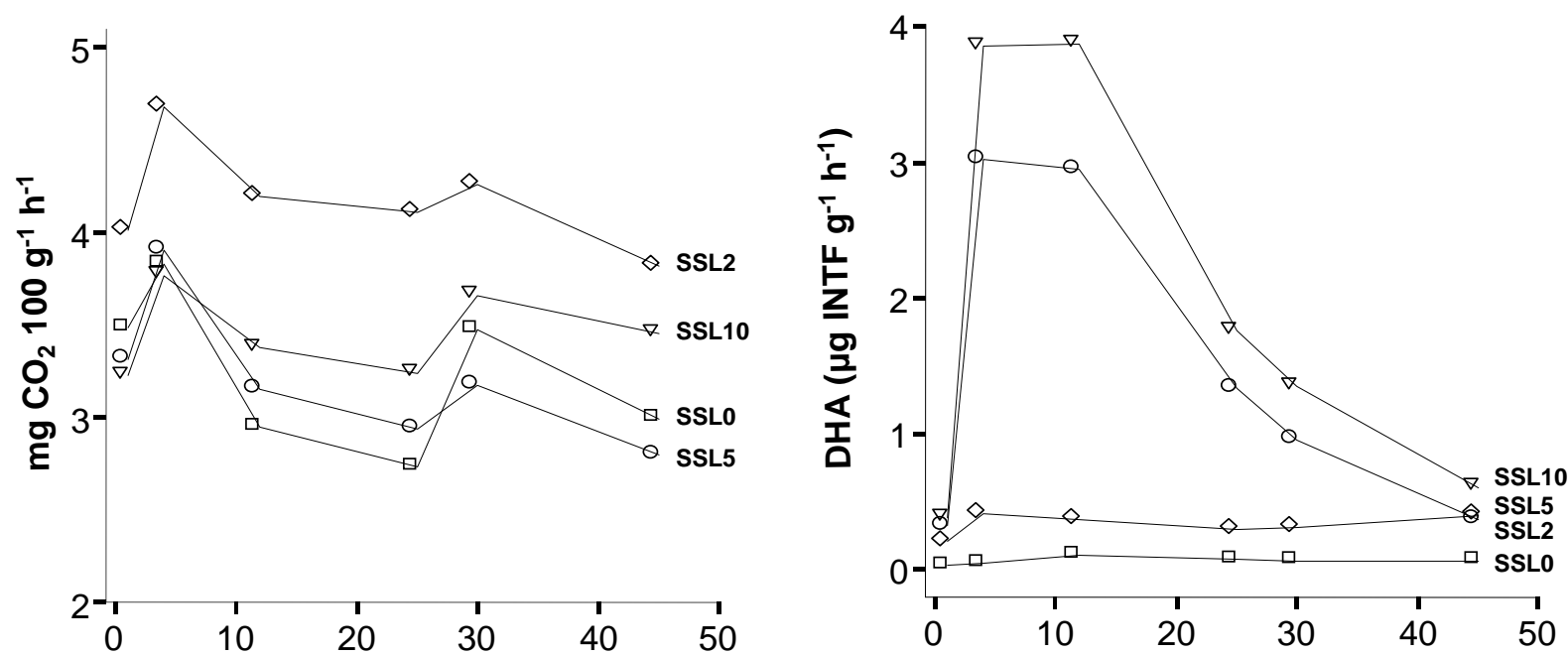

Incubation time (d)

Figure 2. Evolution during incubation of soil induced respiration (left) and dehydrogenase activity (right) for limed Nerva soil $\left(\mathrm{NC}_{\mathrm{L}}\right)$ amended with stabilized sewage sludge (SSL) at $0,2,5$ and $10 \%$. 


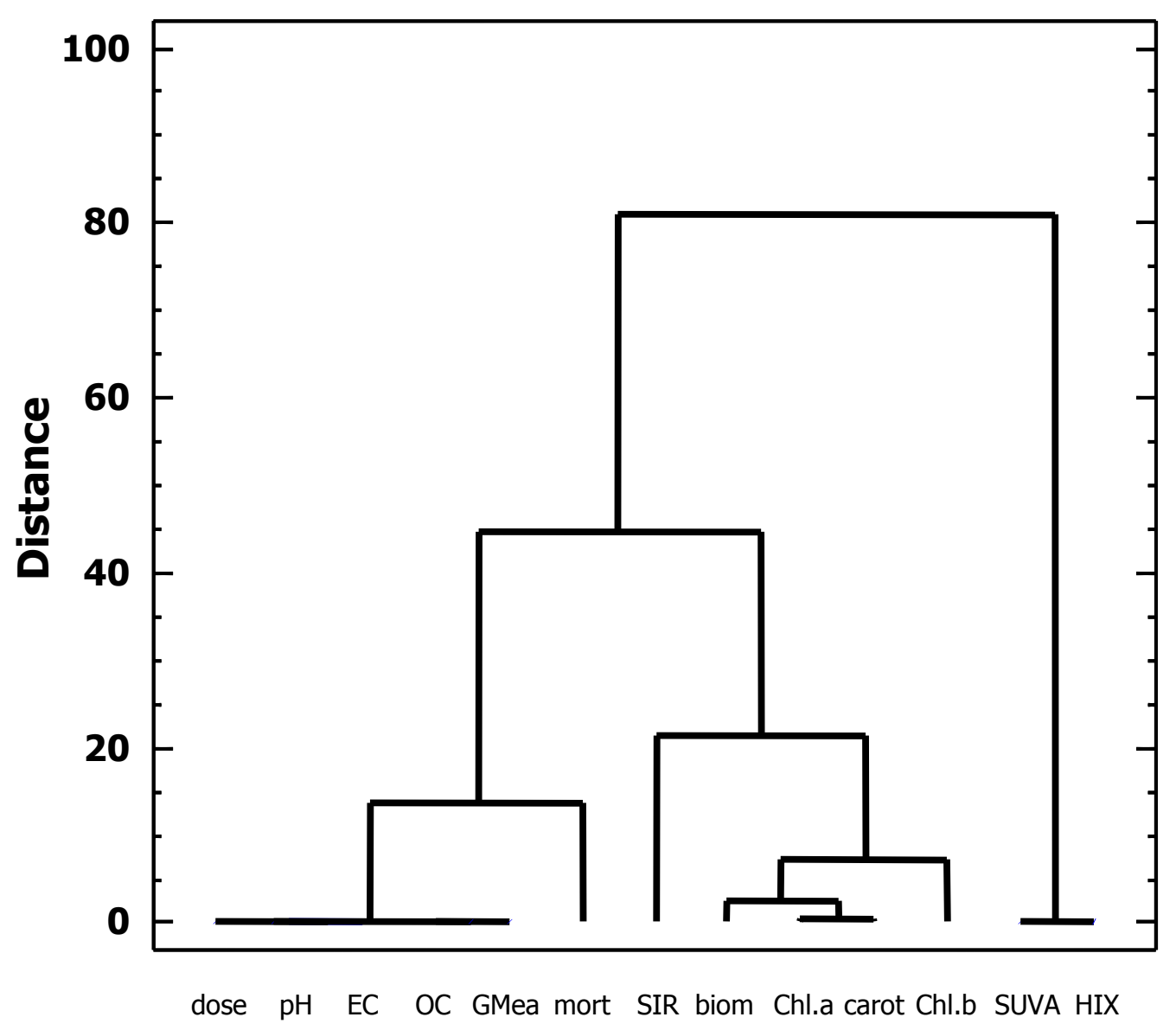

Figure 3. Dendrogram for hierarchical clustering of soil and plant variables 
Table 1. Selected properties of non-amended and amended mine soil with stabilized sewage sludge (SSL) sampled at the end of the incubation study. Values are means of 3 replicates.

\begin{tabular}{|c|c|c|c|c|c|c|c|c|c|c|c|c|c|}
\hline \multirow[b]{2}{*}{$\begin{array}{l}\text { SSL } \\
\text { dose }(\%)\end{array}$} & \multicolumn{3}{|c|}{ Chemical properties } & \multicolumn{6}{|c|}{$\begin{array}{l}\text { Enzyme activities } \\
\mu \mathrm{g} \text { substrate } g^{-1} h^{-1}\end{array}$} & \multicolumn{2}{|c|}{ Microbial properties } & \multicolumn{2}{|c|}{ Soil solution } \\
\hline & $\mathrm{pH}$ & $\begin{array}{c}\mathrm{EC} \\
\mathrm{dS} \mathrm{\textrm {m } ^ { - 1 }}\end{array}$ & $\begin{array}{l}\mathrm{OC} \\
\%\end{array}$ & DHA & Glu & AlkP & Pro & Aryl & GMea & 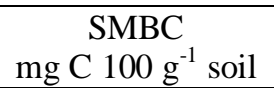 & $\begin{array}{c}\text { SIR } \\
\mathrm{mg} \mathrm{CO}_{2} 100 \mathrm{~g}^{-1} \mathrm{~h}^{-1}\end{array}$ & SUVA & HIX \\
\hline 0 & 7.14 & 2.25 & 1.47 & 0.060 & 10.2 & 2.63 & 0.28 & 0.185 & 0.61 & 67.4 & 2.99 & 1.88 & 5.74 \\
\hline 2 & 7.24 & 2.60 & 1.91 & 0.396 & 108 & 78.4 & 48.2 & 6.39 & 15.9 & 85.9 & 3.82 & 1.25 & 1.91 \\
\hline 5 & 7.58 & 3.21 & 3.02 & 2.798 & 109 & 305 & 98.4 & 16.2 & 43.1 & 63.2 & 2.80 & 1.01 & 1.35 \\
\hline 10 & 7.69 & 4.11 & 3.10 & 3.664 & 173 & 530 & 181 & 14.9 & 61.9 & 77.7 & 3.45 & 0.94 & 1.02 \\
\hline
\end{tabular}

EC: electrical conductivity. OC: organic carbon. DHA: dehydrogenase activity. Glu: $\beta$-glucosidase. AlkP: alkyl phosphatase. Pro: protease. Aryl: arylsulfatase. GMea: geometric mean of the enzyme actitivies. SMBC: soil microbial biomass C. SIR: soil induced respiration. SUVA: specific UV absorbance. HIX: humification index. 
Table 2. Parameters in the plants growing in non-amended and amended mine soil with stabilized sewage sludge (SSL). Values are means of 3 replicates \pm standard deviation.

\begin{tabular}{|c|c|c|c|c|c|c|c|}
\hline Species & $\begin{array}{l}\text { SSL } \\
\text { dose }(\%)\end{array}$ & Germination (\%) & Mortality (\%) & Biomass (g) & Chl. a (mg g $\left.{ }^{-1}\right)$ & Chl. $b\left(\mathrm{mg} \mathrm{g}^{-1}\right)$ & Carotenoids $\left(\mathrm{mg} \mathrm{g}^{-1}\right)$ \\
\hline Ahipa & $\begin{array}{l}0 \\
2 \\
10\end{array}$ & $\begin{array}{c}87 \pm 0 \\
64 \pm 28 \\
69 \pm 4\end{array}$ & $\begin{array}{l}3 \pm 4 \\
3 \pm 4 \\
9 \pm 9\end{array}$ & $\begin{array}{l}4.78 \pm 1.13 \\
4.76 \pm 2.19 \\
3.38 \pm 1.10\end{array}$ & $\begin{array}{l}2.56 \pm 0.45 \\
2.47 \pm 0.23 \\
2.43 \pm 0.48\end{array}$ & $\begin{array}{l}0.83 \pm 0.15 \\
0.76 \pm 0.08 \\
0.77 \pm 0.14\end{array}$ & $\begin{array}{l}0.65 \pm 0.11 \\
0.63 \pm 0.04 \\
0.59 \pm 0.17\end{array}$ \\
\hline Rye grass & $\begin{array}{l}0 \\
2 \\
10\end{array}$ & $\begin{array}{l}91 \pm 9 \\
94 \pm 5 \\
88 \pm 5\end{array}$ & $\begin{array}{l}3 \pm 6 \\
0 \pm 0 \\
0 \pm 0\end{array}$ & $\begin{array}{l}0.07 \pm 0.01 \\
0.24 \pm 0.02 \\
0.13 \pm 0.01\end{array}$ & $\begin{array}{l}1.08 \pm 0.16 \\
1.57 \pm 0.27 \\
1.76 \pm 0.33\end{array}$ & $\begin{array}{l}0.56 \pm 0.05 \\
0.67 \pm 0.10 \\
0.92 \pm 0.23\end{array}$ & $\begin{array}{l}0.23 \pm 0.09 \\
0.38 \pm 0.06 \\
0.32 \pm 0.06\end{array}$ \\
\hline Tomato & $\begin{array}{l}0 \\
2 \\
10\end{array}$ & $\begin{array}{c}92 \pm 8 \\
81 \pm 13 \\
92 \pm 8\end{array}$ & $\begin{array}{c}6 \pm 11 \\
0 \pm 0 \\
73 \pm 24\end{array}$ & $\begin{array}{l}0.38 \pm 0.08 \\
1.12 \pm 0.30 \\
0.23 \pm 0.05\end{array}$ & $\begin{array}{l}0.99 \pm 0.14 \\
2.04 \pm 0.28 \\
2.21 \pm 0.43\end{array}$ & $\begin{array}{l}0.34 \pm 0.06 \\
0.71 \pm 0.09 \\
0.75 \pm 0.13\end{array}$ & $\begin{array}{l}0.23 \pm 0.04 \\
0.53 \pm 0.08 \\
0.52 \pm 0.09\end{array}$ \\
\hline
\end{tabular}

